\title{
Towards Bionic Noses
}

DOI:

10.1108/SR-10-2016-0238

\section{Document Version}

Accepted author manuscript

Link to publication record in Manchester Research Explorer

\section{Citation for published version (APA):}

Persaud, K. (2017). Towards Bionic Noses. Sensor Review, 37(2), 165-171. https://doi.org/10.1108/SR-10-20160238

\section{Published in:}

Sensor Review

\section{Citing this paper}

Please note that where the full-text provided on Manchester Research Explorer is the Author Accepted Manuscript or Proof version this may differ from the final Published version. If citing, it is advised that you check and use the publisher's definitive version.

\section{General rights}

Copyright and moral rights for the publications made accessible in the Research Explorer are retained by the authors and/or other copyright owners and it is a condition of accessing publications that users recognise and abide by the legal requirements associated with these rights.

\section{Takedown policy}

If you believe that this document breaches copyright please refer to the University of Manchester's Takedown Procedures [http://man.ac.uk/04Y6Bo] or contact uml.scholarlycommunications@manchester.ac.uk providing relevant details, so we can investigate your claim.

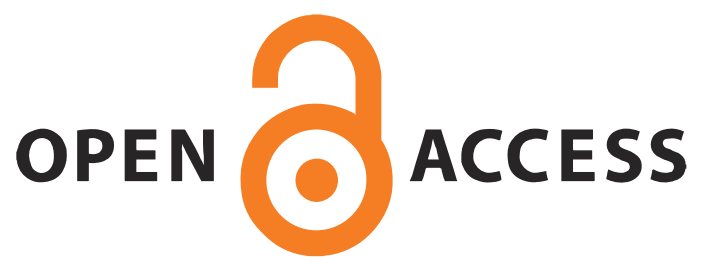




\section{Towards Bionic Olfaction}

\section{Krishna Persaud}

\section{School of Chemical Engineering, The University of Manchester, Manchester M13 9PL, UK}

\section{Abstract}

Electronic nose technologies are moving rapidly towards hybrid bioelectronic systems where biological odour recognition elements from the olfactory pathways of vertebrates and insects are being utilised to construct new "bionic noses" that can be used in industrial applications. Recent progress is reviewed.

\section{Introduction}

Devices capable of detecting and discrimination of complex mixtures of volatile chemicals were named "electronic noses" back in the early 1990's (Gardner and Bartlett, 1994). The operational concepts are loosely based on analogies of how biological system is able to sensitively detect, discriminate and recognise odours based on arrays of sensors that have a broad but overlapping selectivity to different chemical species. Using these ideas, and realising that a combinatorial coding system probably existed in biological olfaction, Persaud and Dodd (Persaud and Dodd, 1982) demonstrated an operational device, based on combining the signals from three metal oxide sensors, which was able to discriminate a number of different odorous compounds. The potential of "electronic noses" as new "analytical devices" stimulated world-wide research and the formation of many companies that sold instruments targeted at the food, environmental, medical, industrial process control, chemical industries and others. Many of these companies grew rapidly, but most failed after a few years as customers realised that these instruments simply could not do what the human nose can do. There were severe technological limitations in the types of sensor technologies available, lack of understanding of the sampling techniques necessary for particular applications, problems of sensor drift, calibration of an array of sensors, data processing, pattern recognition, and fundamentally lack of understanding of how "biological noses" really work, or that the questions asked of such systems are different from that asked of analytical instruments such as a gas chromatograph coupled to a mass spectrometer. These challenges have continued to stimulate multidisciplinary research in the field worldwide over the last few decades. Despite the commercial failures of the past, so-called "electronic noses" have pervaded into a huge number of specialised applications from controlling the quality of coffee (Loutfi et al., 2015) to breath analysis for medical diagnosis (Scarlata et al., 2015; Wilson, 2015; De Vincentis et al., 2016; Moon et al., 2016). Until recently the sensor technologies utilised have predominantly been based on metal oxide gas sensors (Barsan and Weimar, 2001), organic conducting polymer chemoresistor sensors (Persaud, 2005), catalytic sensors (Gall, 1993), phtalocyanines (Di Natale et al., 2014) or materials immobilised on quartz crystal microbalances or surface acoustic wave sensors (Länge, Rapp and Rapp, 2008), electrochemical gas sensors (Bhoga and Singh, 2007), catalytic gate semiconductors (Lundström et al., 1993), or organic materials with optical properties that change on exposure to a gas (Qazi, Mohammad and Akram, 2012). Recent innovations include nanowires (Sberveglieri et al., 2012), nanofibres (MacAgnano et al., 2011), graphene (Yuan and Shi, 2013), quantum dots (Freeman and Willner, 2012) and others. 
Emerging aspects are hybrid "bionic systems" that function more like "biological noses". With increased understanding of how the chemical senses and the brain function in biology - an emerging field of "neuromorphic olfaction" has arisen (Vanarse, Osseiran and Rassau, 2016). Important components are olfactory receptor proteins and soluble proteins found the periphery of olfaction called odorant binding proteins. The idea is that these proteins can be incorporated into transducers and function as biorecognition elements for volatile compounds of interest.

\section{Olfactory Receptors}

The discovery of an unexpectedly large odorant receptor (OR) family in mammals by Buck and Axel (Buck and Axel, 1991), opened the gateway to understanding molecular aspects of olfaction. ORs are transmembrane proteins from the family of GPCRs (G-protein coupled receptors), coupled to two main signal transduction pathways - the cyclic AMP pathway or the phosphatidylinositol pathway, that open ion channels present in the cell membrane, resulting in a change in membrane potential (Figure 1). Peripheral discrimination of odours works through a reciprocal combinatorial code in which one chemical can be detected by different ORs and one OR can detect a group of different chemicals (i.e. the same percept used in "electronic noses") as shown in Figure 2. To understand the ligand binding characteristics of individual olfactory receptors, cultures of olfactory neurons are being screened using large sets of diverse odours (Reisert and Restrepo, 2009) with the use of computational biology (Crasto, 2011). It is clear that some receptors are finely tuned and others very broadly tuned (Poivet et al., 2016). Chemosensory systems are incredibly complex (Mombaerts, 2001). Olfactory sensory neurons (OSNs) are arranged in several chemosensory compartments in the nose. Distinct ORs are located in their chemosensory membranes and there are hundreds of different receptor types. They are categorized into several receptor families, and this large and complex receptor repertoire forms the basis for the enormous chemosensory capacity of the olfactory system (Fleischer, 2009). Insect olfaction is also complex (Galizia, 2010) - the receptors are heterodimeric proteins that function as ion channels in the cell membrane(Sato et al., 2008).

\section{Odorant Binding Proteins}

Odorant molecules need to traverse an aqueous interface before reaching olfactory receptor neurons. In vertebrates, this is the nasal mucus and in insects, the sensillar lymph. The composition of this interface is complex and odorants interact with protein components. In both insects and vertebrates, these include OBPs (odorant-binding proteins)(Pelosi and Margolis, 1994)(Vogt, Prestwich and Lerner, 1991). OBPs of vertebrates belong to the family of lipocalin proteins (containing an eight-stranded beta-barrel structure lining a hydrophobic pocket), while those of insects are folded into alpha-helical domains (Figure 3). Unlike ORs, they are small water soluble proteins thought to facilitate the binding of hydrophobic molecules and help transport to the olfactory receptors. Many DNA sequences of OBPs are available, together with X-ray structures. In insects, OBPs contribute to the sensitivity of the olfactory system by transporting odorants through the antenna sensillar lymph. Mechanisms of interaction between OBPs or OBP/ligand complex with olfactory receptors are not well understood. There are several types of OBPs with different ligand selectivity that are expressed in very high concentrations. There are a variety of combinational patterns between different OBPs and ligands, but exclusive affinity for one OBP to specific binding ligands. There are also complex interactions between OBP/ligand complex and transmembrane proteins (olfactory receptors or sensory neuron membrane proteins)(Fan et al., 2011). 
Similar proteins are found in the urine of rodents. The major urinary proteins (MUPs) are proteins found in urine of adult male mice and rats (Cavaggioni and Mucignat-Caretta, 2000). MUPs form part of the lipocalin protein family, like OBPs. MUPs bind small natural odorant molecules in a hydrophobic pocket with medium affinity, and are excreted in the field, with bound odorants. The odorants are then released slowly in air giving a long lasting olfactory marker. These proteins play complex roles in chemosensory signalling among rodents (Hurst et al., 2001) (Mucignat-Caretta and Caretta, 2014).

\section{Towards Bionic Noses}

Olfactory tissues and live olfactory cells have been used as recognition elements to develop biosensors for the detection and discrimination of specific odorants (Wang and Liu, 2015) (Liu et al., 2010). Due to the need to keep cells alive, these approaches are restricted to research laboratories and ORs and other olfactory-related proteins such as OBPs have increasingly become a source of materials for biosensors. Unlike living tissue and cells, they have much higher stability, are active for long periods, and do not require the maintenance of cell and tissue cultures. To achieve robust biorecognition elements, much attention has been paid to the production of functional ORs. They need to maintain their natural structures and native functions to recognize their natural ligands and they should have a long shelf life. Although it is possible to extract ORs from living olfactory tissues, it is more efficient to use advances in molecular biology and biotechnology for cell-based OR production (Du et al., 2013). ORs can be expressed in cell lines such as human embryonic kidney (HEK) or yeast cells and then extracted. The expressed ORs take up functional conformations in the cell membranes. The responses to odorants can be measured e.g using a light addressable potentiometric device (Figure 4 a). The cell membranes can also be extracted and immobilised on to various kinds of transducers to produce functional olfactory sensors that produce an electrical signal when a volatile compound is presented. Nanobiosensors based on single ORs anchored between nanoelectrodes were described (Akimov et al., 2008). Molecular biology can allow modifications to the protein to graft tags or functional groups that aid in immobilisation of the protein on to a transducer. Since cell based expression methods are expensive, cell free protein synthesis methods are exploiting the cellular protein synthesis machinery to synthesise proteins directly outside intact cells using exogenous messenger RNA (mRNA) or DNA as a template (Katzen, Chang and Kudlicki, 2005). The production of human ORs in a cell free system was demonstrated (Kaiser et al., 2008), yield being optimised using specialised detergents to solubilise these membrane bound proteins (Corin et al., 2011) so that milligram quantities of olfactory receptors can be rapidly produced. Using computational modelling methods, the binding domains of ORs can be examined to determine binding orientation and affinity to ligands. Hence, synthetic peptides that emulate the binding site can be made e.g. a number of olfactory receptors for sensitivity to alcohols were screened using computational methods, a suitable peptide sequence was deduced, synthesised and immobilised on to quartz crystal microbalances (Figure 4b) giving a sensor responsive to alcohols (Sankaran, Panigrahi and Mallik, 2011).

Odorant binding proteins are good candidates for use in sensors for detecting volatile chemicals. Both insect and vertebrate OBPs are extremely stable to temperature, organic solvents and proteolytic digestion. Some, like the pig OBP bind a variety of different structures, others are more narrowly tuned to few odorant structures, but in general, OBPs do not exhibit very high specificity (Pelosi et al., 2014). 
A "bio-electronic nose" for vapour phase detection of odorant molecules based on an array of five SAW resonators coated with three types of odorant-binding proteins (OBPs) produced good responses to octenol and carvone (Di Pietrantonio et al., 2013). Cantilever sensors based on polycrystalline diamond surfaces with pig OBP (Manai et al., 2014). A new bio-sensing platform based on major urinary proteins (MUPs) from the mouse as chemical recognition elements was demonstrated (Scorsone et al., 2016) using SAW devices coated with diamond enabling covalent attachment of the proteins. They detected 2,4-Dinitrotoluene, 4-Nitrotoluene, and 2-Isobutyl-3methoxypyrazine at ppb levels (Figure 5).

Recent advances in organic field effect transistors for gas sensors or biosensors (Torsi et al., 2013) have led to exquisite limits of detection as well as discrimination of chiral molecules (Mulla et al., 2015). By modulation of capacitance of the gate of the field effect transistor with immobilised OBP, sensitivities in the femtomolar concentrations can be achieved. This gives promise for devices based on hybrids of organic semiconductors that can produce a new generation of sensing devices.

\section{Signal processing}

Marco and co-workers (Marco et al., 2014) review novel computing paradigms and biologically motivated artefacts for chemical sensing taking inspiration from the biological olfactory pathway. A biomimetic demonstrator was built featuring a large scale sensor array (65K elements) in conducting polymer technology mimicking the olfactory receptor neuron layer (Beccherelli et al., 2010). Biomimetic algorithms have been implemented that integrates computational models of the main anatomic building blocks in the olfactory pathway: the olfactory bulb, and olfactory cortex in vertebrates (or the antennal lobe and mushroom bodies in the insect). These have been tested with an odour robot with navigation capabilities in mixed chemical plumes.

\section{Conclusion}

The fascination of how biological systems work so efficiently to sense chemicals in the environment is driving researchers to the creation of "bionic noses". The book "On the Scent" by Paolo Pelosi documents the field of olfaction, together with the drivers for implementing artificial olfaction systems (Pelosi, 2016). Here, this review has necessarily omitted many aspects of "electronic nose" developments. Major drivers are the security, environmental and medical applications, and we shall find the internet of things being a major factor in implementing low cost chemical sensing in networked applications for the future.

Acknowledgement: European Commission FP7-SECURITY Project SNIFFER Grant 285203

\section{References}

Akimov, V., Alfinito, E., Bausells, J., Benilova, I., Paramo, I. C., Errachid, A., Ferrari, G., Fumagalli, L., Gomila, G., Grosclaude, J., Hou, Y., Jaffrezic-Renault, N., Martelet, C., Pajot-Augy, E., Pennetta, C., Persuy, M. A., Pla-Roca, M., Reggiani, L., Rodriguez-Segui, S., Ruiz, O., Salesse, R., Samitier, J., Sampietro, M., Soldatkin, A. P., Vidic, J. and Villanueva, G. (2008) 'Nanobiosensors based on individual olfactory receptors', Analog Integrated Circuits and Signal Processing, 57(3), pp. 197-203. doi: 10.1007/s10470-007-9114-0.

Barsan, N. and Weimar, U. (2001) 'Conduction model of metal oxide gas sensors', Journal of Electroceramics, 7(3), pp. 143-167. doi: 10.1023/A:1014405811371. 
Beccherelli, R., Zampetti, E., Pantalei, S., Bernabei, M. and Persaud, K. C. (2010) 'Design of a very large chemical sensor system for mimicking biological olfaction', Sensors and Actuators, B: Chemical, 146(2), pp. 446-452. doi: 10.1016/j.snb.2009.11.031.

Bhoga, S. S. and Singh, K. (2007) 'Electrochemical solid state gas sensors: An overview', Ionics, 13(6), pp. 417-427. doi: 10.1007/s11581-007-0150-7.

Buck, L. and Axel, R. (1991) 'A novel multigene family may encode odorant receptors: a molecular basis for odor recognition.', Cell, 65(1), pp. 175-87. doi: 10.1016/0092-8674(91)90418-X.

Cavaggioni, A. and Mucignat-Caretta, C. (2000) 'Major urinary proteins, alpha(2U)-globulins and aphrodisin.', Biochimica et biophysica acta, 1482(1-2), pp. 218-28. doi: 10.1016/S01674838(00)00149-7.

Corin, K., Baaske, P., Ravel, D. B., Song, J., Brown, E., Wang, X., Wienken, C. J., Jerabek-Willemsen, M., Duhr, S., Luo, Y., Braun, D. and Zhang, S. (2011) 'Designer lipid-like peptides: A class of detergents for studying functional olfactory receptors using commercial cell-free systems', PLoS ONE, 6(11). doi: 10.1371/journal.pone.0025067.

Crasto, C. J. (2011) 'Computational Biology of Olfactory Receptors', NIH Public Access, 4(1), pp. 8-15. doi: 10.2174/157489309787158143.Computational.

Du, L., Wu, C., Liu, Q., Huang, L. and Wang, P. (2013) 'Recent advances in olfactory receptor-based biosensors', Biosensors and Bioelectronics, 42(1), pp. 570-580. doi: 10.1016/j.bios.2012.09.001.

Fan, J., Francis, F., Liu, Y., Chen, J. L. and Cheng, D. F. (2011) 'An overview of odorant-binding protein functions in insect peripheral olfactory reception', Genetics and Molecular Research, pp. 3056-3069. doi: 10.4238/2011.December.8.2.

Fleischer, J. (2009) 'Mammalian olfactory receptors', Frontiers in Cellular Neuroscience, 3(August), p. 9. doi: 10.3389/neuro.03.009.2009.

Freeman, R. and Willner, I. (2012) 'Optical molecular sensing with semiconductor quantum dots (QDs)', Chemical Society Reviews, 41(10), p. 4067. doi: 10.1039/c2cs15357b.

Galizia, G. (2010) 'Insect Olfaction', in The Senses: A Comprehensive Reference, pp. 725-769. doi: 10.1016/B978-012370880-9.00123-7.

Gall, M. (1993) 'The Si-Planar-Pellistor array, a detection unit for combustible gases', Sensors and Actuators: B. Chemical, 16(1-3), pp. 260-264. doi: 10.1016/0925-4005(93)85192-D.

Gardner, J. W. and Bartlett, P. N. (1994) 'A brief history of electronic noses', Sensors and Actuators: B. Chemical, 18(1-3), pp. 210-211. doi: 10.1016/0925-4005(94)87085-3.

Hurst, J. L., Payne, C. E., Nevison, C. M., Marie, A. D., Humphries, R. E., Robertson, D. H. L., Cavaggioni, A. and Beynon, R. J. (2001) 'Individual recognition in mice mediated by major urinary proteins.', Nature, 414(6864), pp. 631-634. doi: 10.1038/414631a.

Kaiser, L., Graveland-Bikker, J., Steuerwald, D., Vanberghem, M., Herlihy, K. and Zhang, S. (2008) 'Efficient cell-free production of olfactory receptors: detergent optimization, structure, and ligand binding analyses.', Proceedings of the National Academy of Sciences of the United States of America, 105(41), pp. 15726-15731. doi: 10.1073/pnas.0804766105.

Katzen, F., Chang, G. and Kudlicki, W. (2005) 'The past, present and future of cell-free protein synthesis', Trends in Biotechnology, pp. 150-156. doi: 10.1016/j.tibtech.2005.01.003. 
Länge, K., Rapp, B. E. and Rapp, M. (2008) 'Surface acoustic wave biosensors: A review', Analytical and Bioanalytical Chemistry, pp. 1509-1519. doi: 10.1007/s00216-008-1911-5.

Liu, Q., Cai, H., Xu, Y., Li, Y., Li, R. and Wang, P. (2006) 'Olfactory cell-based biosensor: A first step towards a neurochip of bioelectronic nose', Biosensors and Bioelectronics, 22(2), pp. 318-322. doi: 10.1016/j.bios.2006.01.016.

Liu, Q., Ye, W., Xiao, L., Du, L., Hu, N. and Wang, P. (2010) 'Extracellular potentials recording in intact olfactory epithelium by microelectrode array for a bioelectronic nose', Biosensors and Bioelectronics, 25(10), pp. 2212-2217. doi: 10.1016/j.bios.2010.02.024.

Loutfi, A., Coradeschi, S., Mani, G. K., Shankar, P. and Rayappan, J. B. B. (2015) 'Electronic noses for food quality: A review', Journal of Food Engineering, pp. 103-111. doi:

10.1016/j.jfoodeng.2014.07.019.

Lundström, I., Svensson, C., Spetz, A., Sundgren, H. and Winquist, F. (1993) 'From hydrogen sensors to olfactory images - twenty years with catalytic field-effect devices', Sensors and Actuators: $B$. Chemical, 13(1-3), pp. 16-23. doi: 10.1016/0925-4005(93)85313-Y.

MacAgnano, A., Zampetti, E., Pantalei, S., De Cesare, F., Bearzotti, A. and Persaud, K. C. (2011) 'Nanofibrous PANI-based conductive polymers for trace gas analysis', Thin Solid Films, 520(3), pp. 978-985. doi: 10.1016/j.tsf.2011.04.175.

Manai, R., Scorsone, E., Rousseau, L., Ghassemi, F., Possas Abreu, M., Lissorgues, G., Tremillon, N., Ginisty, H., Arnault, J. C., Tuccori, E., Bernabei, M., Cali, K., Persaud, K. C. and Bergonzo, P. (2014) 'Grafting odorant binding proteins on diamond bio-MEMS', Biosensors and Bioelectronics, 60, pp. 311-317. doi: 10.1016/j.bios.2014.04.020.

Marco, S., Gutiérrez-Gálvez, A., Lansner, A., Martinez, D., Rospars, J. P., Beccherelli, R., Perera, A., Pearce, T. C., Verschure, P. F. M. J. and Persaud, K. (2014) 'A biomimetic approach to machine olfaction, featuring a very large-scale chemical sensor array and embedded neuro-bio-inspired computation', Microsystem Technologies, 20(4-5), pp. 729-742. doi: 10.1007/s00542-013-2020-8.

Mombaerts, P. (2001) 'How smell develops.', Nature neuroscience, 4 Suppl(november), pp. 1192-8. doi: $10.1038 / \mathrm{nn} 751$.

Moon, H. G., Jung, Y., Han, S. D., Shim, Y.-S., Shin, B., Lee, T., Kim, J.-S., Lee, S., Jun, S. C., Park, H.-H., Kim, C. and Kang, C.-Y. (2016) 'Chemiresistive Electronic Nose toward Detection of Biomarkers in Exhaled Breath', ACS APPLIED MATERIALS \& INTERFACES. WASHINGTON, DC USA: AMER CHEMICAL SOC, 8(32), pp. 20969-20976. doi: 10.1021/acsami.6b03256.

Mucignat-Caretta, C. and Caretta, A. (2014) 'Message in a bottle: Major urinary proteins and their multiple roles in mouse intraspecific chemical communication', Animal Behaviour, 97, pp. 255-263. doi: 10.1016/j.anbehav.2014.08.006.

Mulla, M. Y., Tuccori, E., Magliulo, M., Lattanzi, G., Palazzo, G., Persaud, K. and Torsi, L. (2015) 'Capacitance-modulated transistor detects odorant binding protein chiral interactions.', Nature communications, 6, p. 6010. doi: 10.1038/ncomms7010.

Di Natale, C., Paolesse, R., Martinelli, E. and Capuano, R. (2014) 'Solid-state gas sensors for breath analysis: A review', Analytica Chimica Acta. Elsevier B.V., 824, pp. 1-7. doi: 10.1016/j.aca.2014.03.014.

Pelosi, P. (2016) On the Scent: A journey through the science of smell. Oxford: Oxford University Press. 
Pelosi, P. and Margolis, F. (1994) 'Odorant-Binding Proteins', Critical Reviews in Biochemishy andMolecular Biology, 29(3), pp. 199-228. doi: 10.1016/S0083-6729(10)83010-9.

Pelosi, P., Mastrogiacomo, R., lovinella, I., Tuccori, E. and Persaud, K. C. (2014) 'Structure and biotechnological applications of odorant-binding proteins', Applied Microbiology and Biotechnology, 98(1), pp. 61-70. doi: 10.1007/s00253-013-5383-y.

Persaud, K. C. (2005) 'Polymers for chemical sensing', Materials Today, pp. 38-44. doi: 10.1016/S1369-7021(05)00793-5.

Persaud, K. and Dodd, G. (1982) 'Analysis of discrimination mechanisms in the mammalian olfactory system using a model nose.', Nature, 299(5881), pp. 352-5. doi: 10.1088/1751-8113/44/8/085201.

Di Pietrantonio, F., Cannatà, D., Benetti, M., Verona, E., Varriale, A., Staiano, M. and D’Auria, S. (2013) 'Detection of odorant molecules via surface acoustic wave biosensor array based on odorantbinding proteins', Biosensors and Bioelectronics, 41(1), pp. 328-334. doi: 10.1016/j.bios.2012.08.046.

Poivet, E., Peterlin, Z., Tahirova, N., Xu, L., Altomare, C., Paria, A., Zou, D.-J. and Firestein, S. (2016) 'Applying medicinal chemistry strategies to understand odorant discrimination.', Nature communications, 7, p. 11157. doi: 10.1038/ncomms11157.

Qazi, H., Mohammad, a and Akram, M. (2012) 'Recent Progress in Optical Chemical Sensors', Sensors, 12(12), pp. 16522-16556. doi: 10.3390/s121216522.

Reisert, J. and Restrepo, D. (2009) 'Molecular tuning of odorant receptors and its implication for odor signal processing', Chemical Senses, pp. 535-545. doi: 10.1093/chemse/bjp028.

Sankaran, S., Panigrahi, S. and Mallik, S. (2011) 'Olfactory receptor based piezoelectric biosensors for detection of alcohols related to food safety applications', Sensors and Actuators, B: Chemical, 155(1), pp. 8-18. doi: 10.1016/j.snb.2010.08.003.

Sato, K., Pellegrino, M., Nakagawa, T., Nakagawa, T., Vosshall, L. B. and Touhara, K. (2008) 'Insect olfactory receptors are heteromeric ligand-gated ion channels.', Nature, 452(7190), pp. 1002-1006. doi: $10.1038 /$ nature06850.

Sberveglieri, G., Concina, I., Comini, E., Falasconi, M., Ferroni, M. and Sberveglieri, V. (2012) 'Synthesis and integration of tin oxide nanowires into an electronic nose', Vacuum, 86(5), pp. 532535. doi: 10.1016/j.vacuum.2011.10.004.

Scarlata, S., Pennazza, G., Santonico, M., Pedone, C. and Antonelli Incalzi, R. (2015) 'Exhaled breath analysis by electronic nose in respiratory diseases.', Expert review of molecular diagnostics, 15(7), pp. 933-56. doi: 10.1586/14737159.2015.1043895.

Scorsone, E., Manai, R., Ricatti, M. J., Redaelli, M., Bergonzo, P., Persaud, K. C. and Mucignat, C. (2016) 'Major Urinary Proteins on Nanodiamond-Based Resonators Toward Artificial Olfaction', IEEE Sensors Journal, 16(17), pp. 6543-6550. doi: 10.1109/JSEN.2016.2585187.

Torsi, L., Magliulo, M., Manoli, K. and Palazzo, G. (2013) ‘Organic field-effect transistor sensors: a tutorial review', Chemical Society Reviews, 42(22), p. 8612. doi: 10.1039/c3cs60127g.

Vanarse, A., Osseiran, A. and Rassau, A. (2016) 'A review of current neuromorphic approaches for vision, auditory, and olfactory sensors', Frontiers in Neuroscience. doi: 10.3389/fnins.2016.00115.

De Vincentis, A., Pennazza, G., Santonico, M., Vespasiani-Gentilucci, U., Galati, G., Gallo, P., Vernile, 
C., Pedone, C., Antonelli Incalzi, R. and Picardi, A. (2016) 'Breath-print analysis by e-nose for classifying and monitoring chronic liver disease: a proof-of-concept study.', Scientific reports. LONDON, ENGLAND: NATURE PUBLISHING GROUP, 6, p. 25337. doi: 10.1038/srep25337.

Vogt, R. G., Prestwich, G. D. and Lerner, M. R. (1991) 'Odorant-binding-protein subfamilies associate with distinct classes of olfactory receptor neurons in insects', Journal of Neurobiology, 22(1), pp. 7484. doi: $10.1002 /$ neu.480220108.

Wang, P. and Liu, Q. (2015) Bioinspired Smell and Taste. doi: 10.1007/978-94-017-7333-1.

Wilson, A. D. (2015) 'Advances in electronic-nose technologies for the detection of volatile biomarker metabolites in the human breath.', Metabolites, 5(1), pp. 140-63. doi: 10.3390/metabo5010140.

Yuan, W. and Shi, G. (2013) 'Graphene-based gas sensors', Journal of Materials Chemistry A, 1(35), p. 10078. doi: 10.1039/c3ta11774j. 


\section{Figure legends}

\section{Figure 1}

Olfactory receptor neuron (lower left). The receptor proteins traverse the cell membrane of the cilia (upper right) - odorants binding to the receptor cause a change in conformation, so that the interaction with a G-protein changes. This causes a chain of events to occur stimulating formation of cyclic AMP (a cell messenger) from ATP that causes further biochemical reactions that lead to opening of ion channels. The ingress of ions into the cell causes a change of electrical potential on the surface of the cell membrane that leads to olfactory transduction.

\section{Figure 2}

Basic principles of electronic noses showing an array of sensors where each sensor has a broad response profile where each sensor may have some cross sensitivity and differences in selectivity to various volatile chemicals. When presenting a coffee odour to the sensor array, a pattern of responses is generated illustrated by the size of the dots. The relative responses across the sensor array are shown as histograms. The multivariate data can be processed by chemometric software to visualise clusters that describe the differences between samples, or can be presented to a pattern recognition engine (typically a neural network) to classify the samples of coffee automatically, based on previously seen exemplar patterns.

\section{Figure 3}

Schematic structure of OBPs. (a) Insect OBP consists of alpha helical domains. (b) Vertebrate OBP contains an eight-stranded beta-barrel structure lining a hydrophobic and belong to the lipocalin family of proteins.

\section{Figure 4}

Measurement odorant responses. (a) One method uses light addressable potentiometric sensors based on silicon to measure the responses of live cells (used by Liu (Liu et al., 2006)). (b) When OR proteins are extracted they can be immobilised on to transducers such as quartz crystal microbalances that produce a change in frequency when ORs are exposed to a pulse of an odour (used by (Sankaran, Panigrahi and Mallik, 2011)).

\section{Figure 5}

MUPS are immobilised on to diamond coated surfaces (a) of a surface acoustic wave sensor (c). When this is exposed to repeated pulses of an odorant - in this case 4-nitrotoluene, a reversible change in frequency is shown in (b). Six different MUP proteins have different sensitivities and selectivities shown by concentration response curves to nitrotoluene (d) so that an array of MUP proteins can make a "bionic nose" (data from (Scorsone et al., 2016) with permission). 


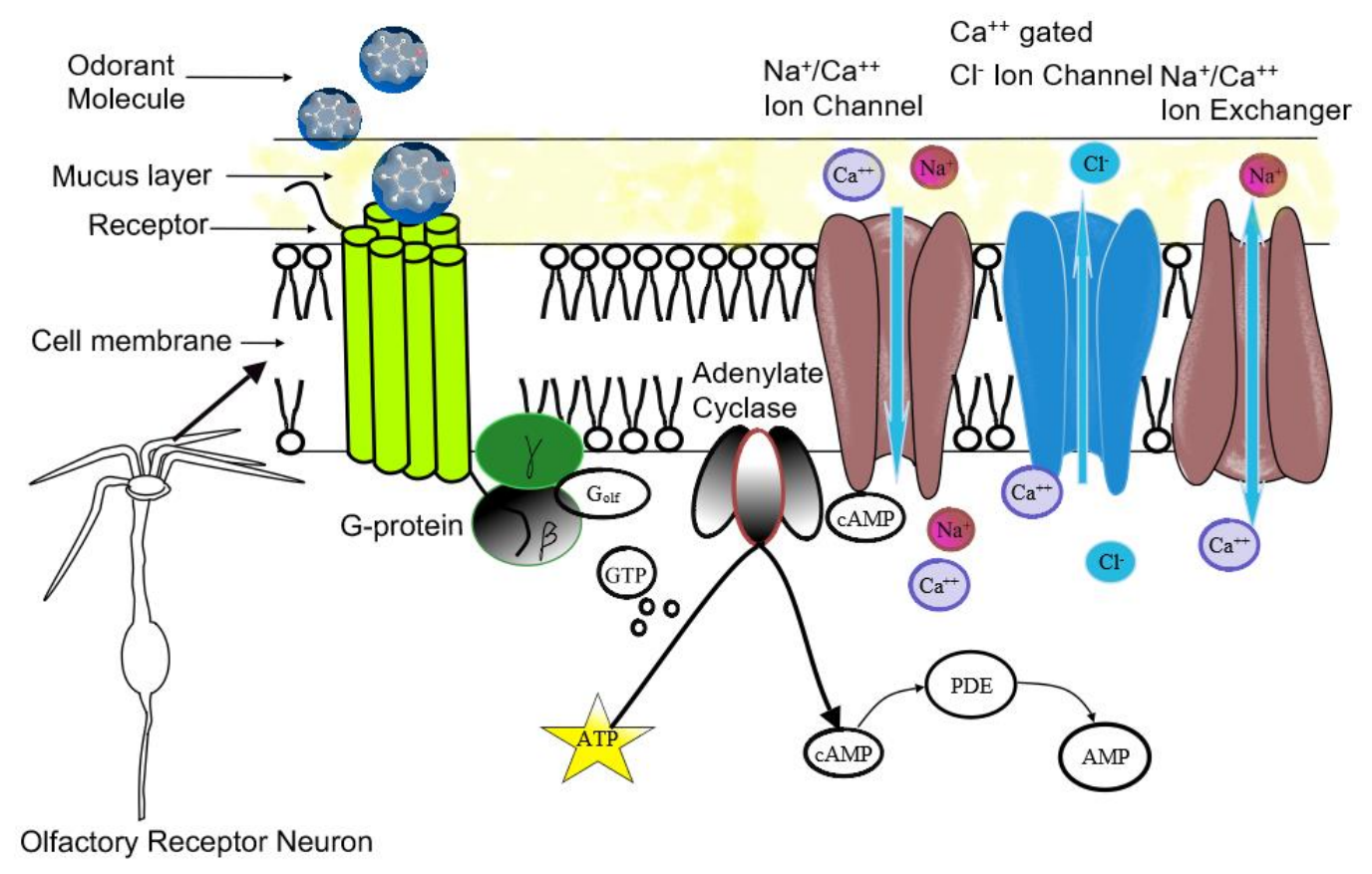

Figure 1 


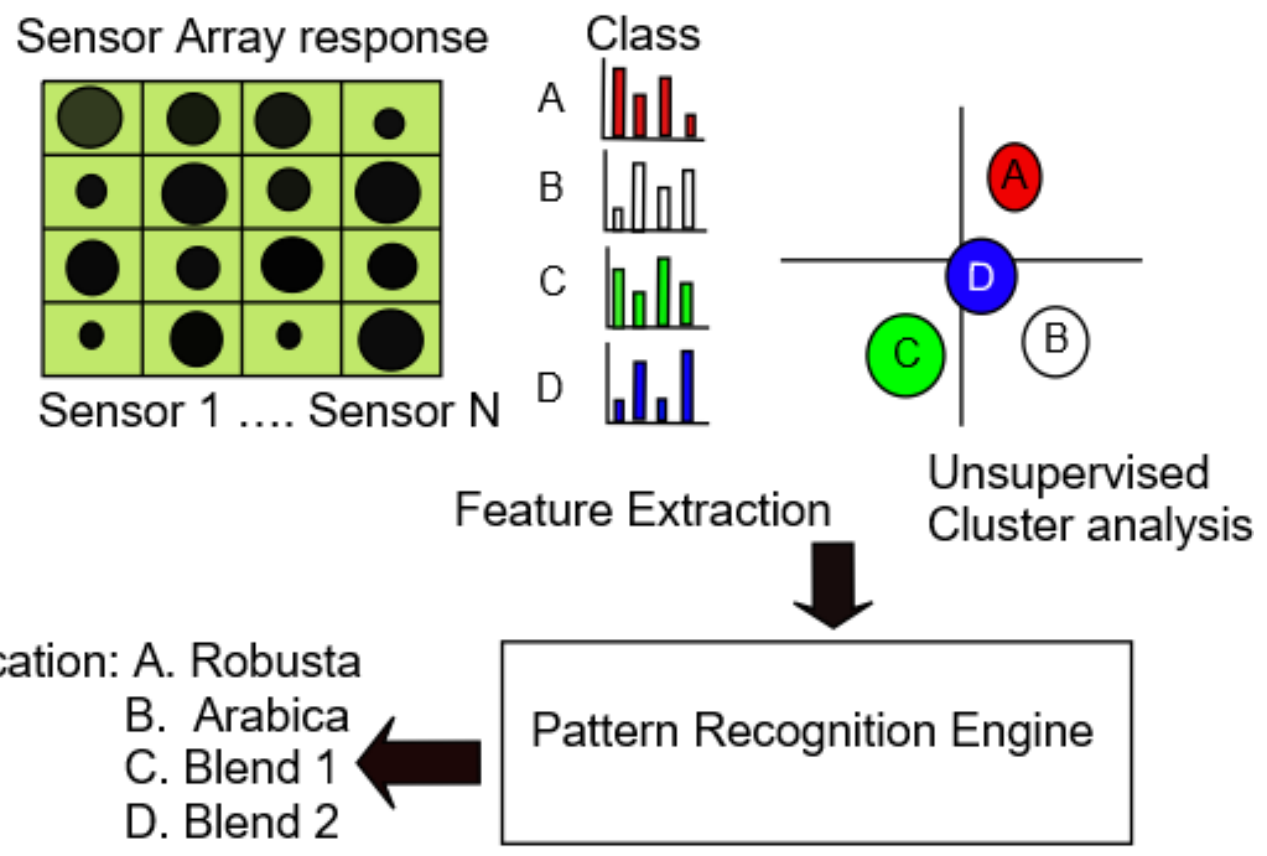

Figure 2 


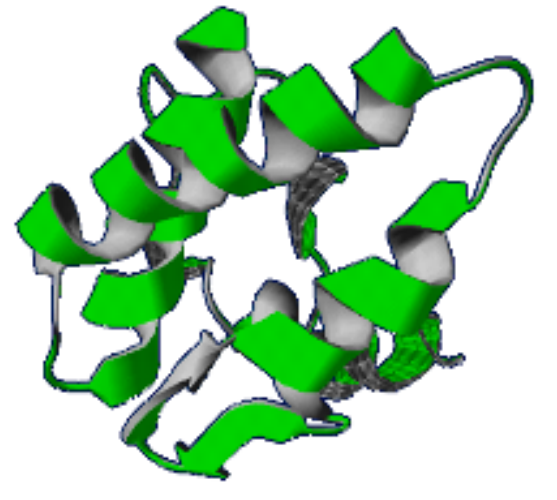

(a)

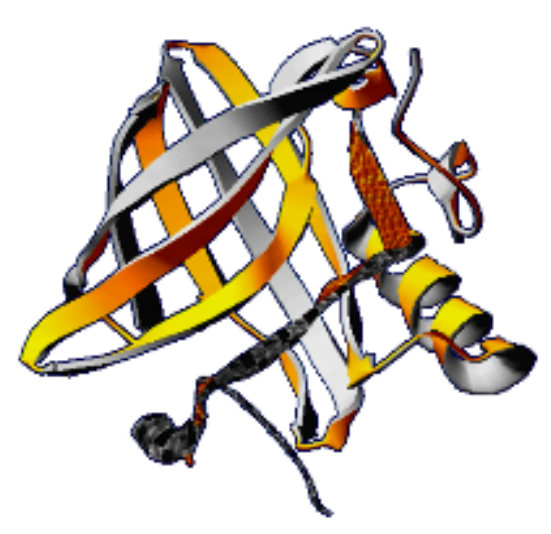

(b)

Figure 3 

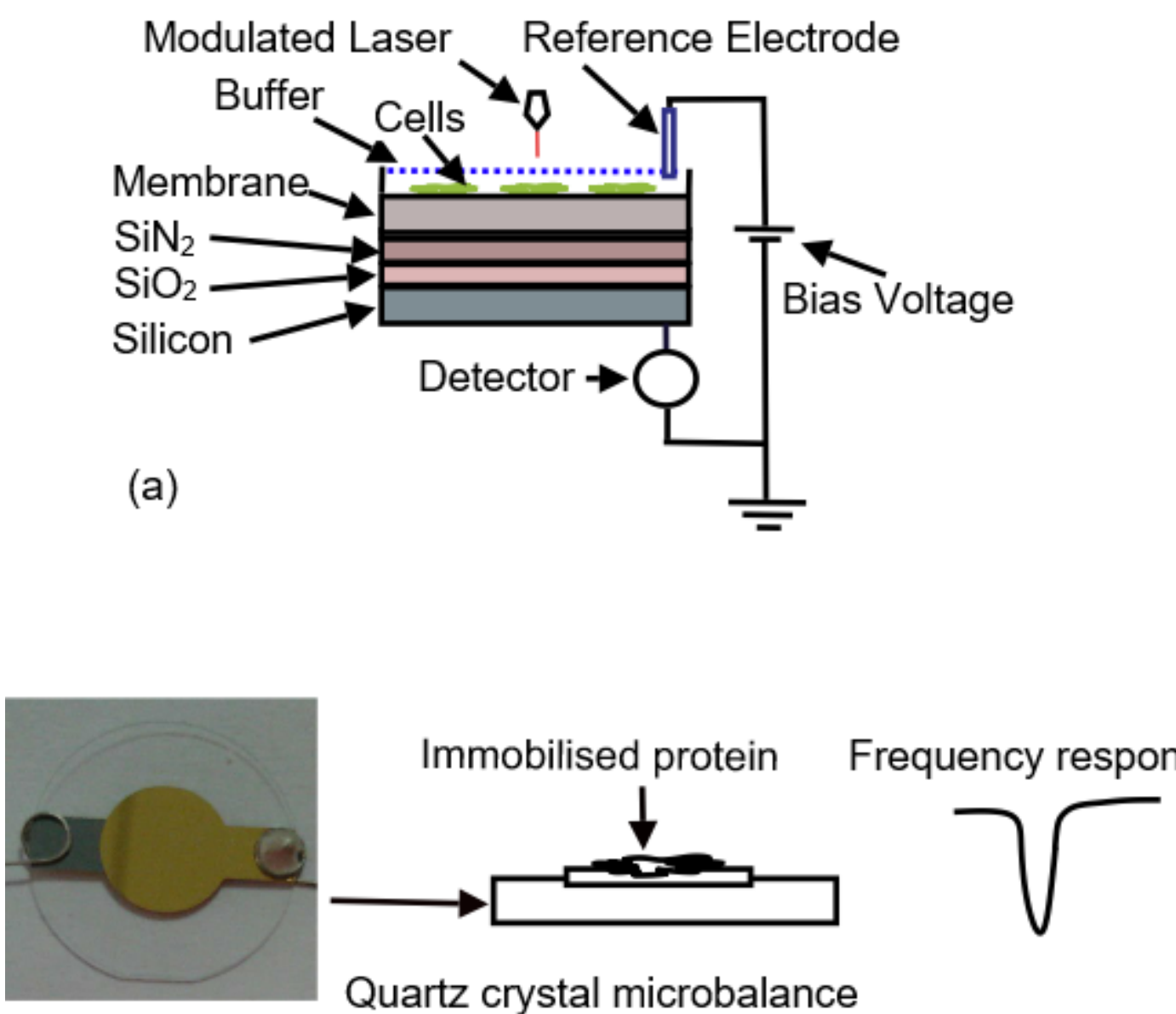

Quartz crystal microbalance

(b) 

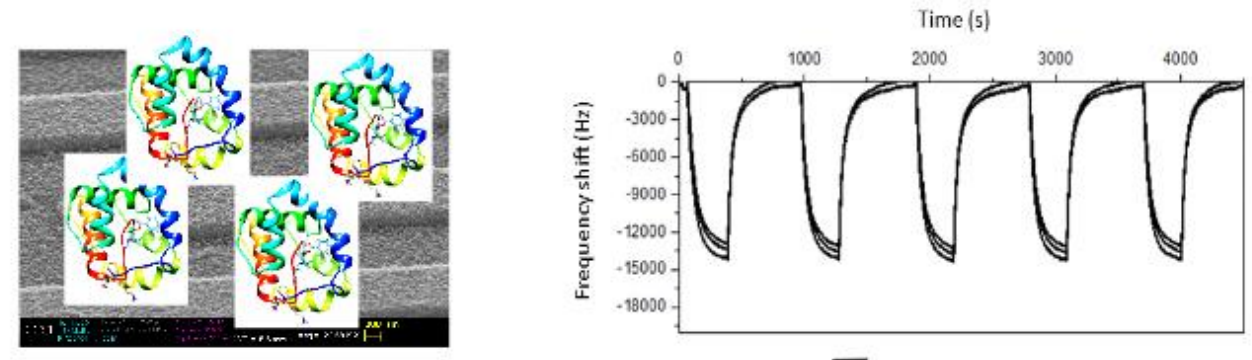

(a)

Sensitive coating

MUPs immobilised on diamond coated SAW device

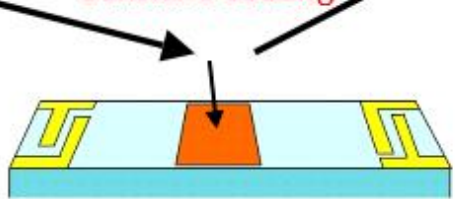

(c) SAW Device (b)

Responses to pulses of 4-Nitrotoluene vapour

\section{Concentration (ppm)}

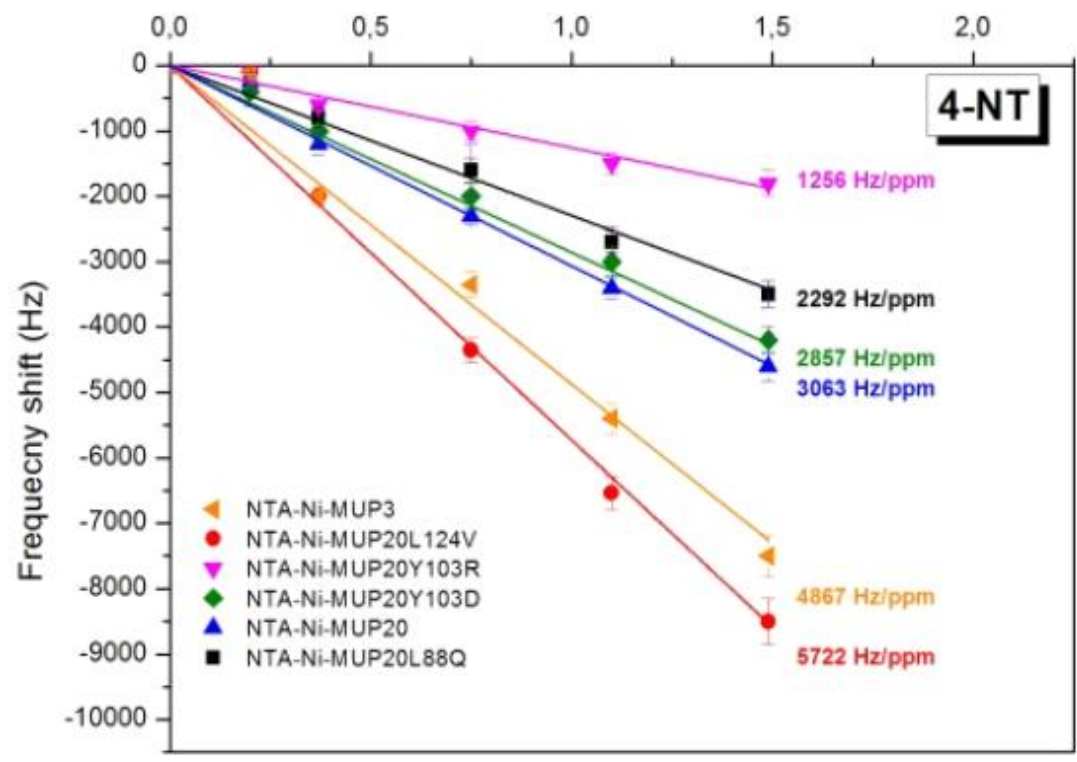

(d) Concentration response curves (MUP mutants) 